\title{
Marketing Maatwerk
}

Citation for published version (APA):

Dellaert, B. G. C. (2003). Marketing Maatwerk. Maastricht Unversity, Department Marketing. https://doi.org/10.26481/spe.20030912bd

Document status and date:

Published: 12/09/2003

DOI:

10.26481/spe.20030912bd

Document Version:

Publisher's PDF, also known as Version of record

\section{Please check the document version of this publication:}

- A submitted manuscript is the version of the article upon submission and before peer-review. There can be important differences between the submitted version and the official published version of record.

People interested in the research are advised to contact the author for the final version of the publication, or visit the DOI to the publisher's website.

- The final author version and the galley proof are versions of the publication after peer review.

- The final published version features the final layout of the paper including the volume, issue and page numbers.

Link to publication

\footnotetext{
General rights rights.

- You may freely distribute the URL identifying the publication in the public portal. please follow below link for the End User Agreement:

www.umlib.nl/taverne-license

Take down policy

If you believe that this document breaches copyright please contact us at:

repository@maastrichtuniversity.nl

providing details and we will investigate your claim.
}

Copyright and moral rights for the publications made accessible in the public portal are retained by the authors and/or other copyright owners and it is a condition of accessing publications that users recognise and abide by the legal requirements associated with these

- Users may download and print one copy of any publication from the public portal for the purpose of private study or research.

- You may not further distribute the material or use it for any profit-making activity or commercial gain

If the publication is distributed under the terms of Article $25 \mathrm{fa}$ of the Dutch Copyright Act, indicated by the "Taverne" license above, 


\section{Marketing Maatwerk}




\section{Colofon}

Ornslagillustrotie: Guus Dellaert

Basisontwerp en realisatie. Unigraphic, Uniwersitert Maastricht

Alte rechten woorbehouden. Miets ust deze uitgave mag worder werveelwoudigd, opgestagen in een geou tomatiseerd gegevensbestand of openbaar gemoakt, zonder voorafgoande schrifte. hike toestemming van de auteur of uitgever. 


\section{Marketing Maatwerk}

Intree rede

Op 12 september 2003

uitgesproken

door

Prof. Dr. Ir. B.G.C. Dellaert

METEOR Hoogleraar Economische

Wetenschappen en Bedrijfskunde aan de Universiteit Maastricht 



\section{Marketing Maatwerk}

Meneer de rector magnificus,

Dames en heren.

Maatwerk rukt op in alleriei aspecten van ons leven. Zo komt in de V.S. zelfs een uiterlijk op maat al onder handbereik. Vorig seizoen liet daar het succesvolle $A B C$ televisieprogramma Extreme Makeover iedere week zien hoe drie personen grondig werden verbouwd om helemaal 'zichzelf' te worden, met het uiterlijk van hun dromen (Chavannes, NRC Handelsblad, 8 juli 2003).

Melissa (28) werd met behulp van een haarbehandeling, borstimplantaten, een operatie aan haar oren en aan haar buik in zes weken veranderd in een fotomodel (website ABC, augustus 2003). Ze is een representant van een maatschappij waarin individuen producten en diensten willen kunnen verwerven die perfect aansluiten bij hun eigen voorkeuren. Zelfs het uiterlijk is daarbij een maakbaar consumptiemiddel geworden dat iedere persoon zo goed mogelijk moet zien vorm te geven en te beheersen.

In deze rede vanmiddag wil ik $u$ graag langs een aantal aspecten in mijn onderzoek voeren die verband houden met het fenomeen maatwerk. Het is een hele stap om van Henry Ford's 'je mag elke kleur auto kiezen zolang het maal zwart is' te komen naar de tegenwoordige zeer flexibele en snelle voortbrengingsketens en -netwerken die grotendeels vraaggestuurd kunnen opereren. In mijn betoog zal ik verkennen onder welke condities producenten en consumenten tot marketing maatwerk kunnen komen. Hierbij stel ik met name het perspectief van de consument als eindafnemer in het productieproces centraal. Als werkdefinitie van marketing maatwerk hanteer ik: het benutten van een woortbrengingsketen met als doel producten en diensten te genereren die door elke consument afzonderlijk kunnen worden gedefinieerd, afgenomen en geconsumeerd. 


\section{De organisatie en maatschappelijk conceptualisatie van maatwerk}

Nog niet zo lang geleden was het zeer kostbaar en tijdrovend om verschillende producten en diensten te maken voor elke individuele consument. Snelle ontwikkelingen in de ICT en de productietechnologie hebben de maatwerkbenadering echter meer en meer haalbaar gemakkt. producenten zoals Nike gebruiken bijvoorbeeld een combinatie van flexibele fabricagetechnologie en moderne communicatiemiddelen om het de consument mogelijk te maken om zelf de kleuren en het materiaal van gymschoenen uit te zoeken op het internet.

Een belangrijke conceptuele grondslag van veel op maatwerk gerichte voortbrengingsprocessen is het denken in modulaire concepten. Modules zijn min of meer zelfstandige componenten die binnen een bepaalde structuur echter relatief snel en gemakkelijk kunnen worden geschakeld orn zo op een flexibele wijze een groter geheel te kunnen opbouwen. In zijn interessante analyse van de grote rol die modulair denken al lange tijd speelt in de cultuur van de V.S. noemt Blair (1988) een aantäl prikkelende en wellicht onverwachte woorbeelden van modulaire systemen die in de Amerikaanse cultuur zijin ontstaan waaronder: wolkenkrabbers, Jazz muziek en het moderne academisch curriculum. Gerneenschappelijk aan deze voorbeelden is dat zij een vast omlijnde basisstructuur hebben waarbinnen in grote vrijheid met componenten kan worden geschoven en gecombineerd.

Maatschappelijk gezien zijn dergelijke structuren ook te herkennen, bijwoorbeeld in trends als individualisering, door Beck gedefinieerd als geïnstitutionaliseerd individualisme (Beck en Beck-Gernsheim, 2002) en in Ritzer's McDonaldisering (Ritzer 1998), als hedendaags efficiënt systeem voor de organisatie van consumptie. In beide trends is er sprake van min of meer onafhankelijk te variëren componenten-respectievelijk het individu en de productiehandeling - die dankzij een nieuw systeem van regels en technologie flexibel en efficiënt kunnen samengaan. Dergelijke maatschappelijke ontwikkelingen vonden veelal hun oorsprong in de V.S. maar bleken ook elders in de wereld succesvol te zijn.

Ook binnen organisatiestructuren is het verschijnsel modularisering terug te vinden. Met name in de verschuiving van traditionele verticale en soms zelfs geheel geïntegreerde voortbrengingsketens naar meer open netwerkstructuren bestaande uit meerdere bedrijven die onderling een zekere set van waarden delen (bijv. Achrol en Kotler 1999). In deze netwerkstructuren vormen kleinere organisaties als het ware orga- 
nisatorische modules die dankzij geavanceerde ICT naar aanleiding van speciffeke klanterwragen snel en flexibel kunnen samerwerken in een groot aantal verschillende verbanden. Deze netwerkstructuren breidlen zich in toenemende mate ook uit in de richting wan integratie met klanten als actieve participanten in het productieproces (bijv. Prahalad en Ramaswamy 2000).

Op het vlak van de productietechnologie dragen modulaire structuren eveneens in hoge mate bij aan de flexibiliteit en snelheid van productie (bijw. Anderson 1997, Sanchez 1999). Met name de rol van de digitalisering van producten en diensten is hierbij van groot belang, omdat deze het in toenemende mate mogelijk maakt om delen van de productie en dienstverlening te standaardiseren en uit te besteden aan goedkope productielanden. China neemt in dit verband een indrukwekkend deel van de internationale productiestructuren voor zijn rekening, door zeer nauwgezet en snel elders gedefinieerde product componenten te produceren en aan te leveren (bijv. NRC Handelsblad 30 augustus 2003). Op deelterreinen van de dienstverlening, speelt India een vergelijkbare rol, bijwoorbeeld bij de uitbesteding vain call-center diensten en softwareontwikkeling. Dergelijke internationale uitbestedingen worden verder ondersteund door bijwoorbeeld internationale tenders en gedetailleerde informatie-uitwisselingen die worden mogelijk gemaakt door moderne informatietechnologieën zoals het Internet.

\section{Wat zijn de voordelen van marketing maatwerk?}

Hoewel het tot stand brengen van marketing maatwerk dus aansluit bij brede maatschappelijke trends en bovendien organisatorisch en technologisch gezien steeds minder moeilijk wordt, is het nog wel de vraag in hoeverre consumenten behoefte hebben aan maatwerkproducten en -diensten, en of deze door de markt zullen worden woortgebracht. 


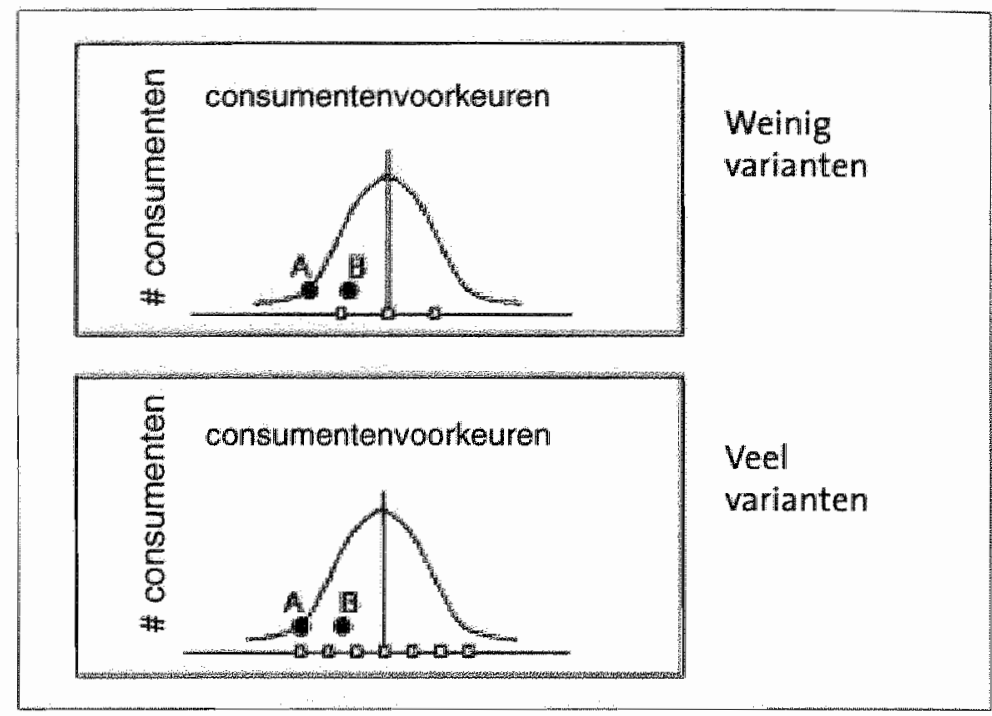

Figuur 1: Productwoorkeuren van consumenten en maatwerk

Als we aannemen dat niet alle consumenten dezelfde smaak hebben, dan is een belangrijk voordleel van maatwerk voor de consument dat maatwerk er in principe voor zorgt dat producten en diensten dichter bij de smaak van elk individu aamsluiten. Ter illustratie kan ik bijvoorbeeld de preferenties van alle individuen voor een bepaald product (bijvoorbeeld nieuwe gymschoenen) op een rechte lijn weergeven die de markt met alle modelvarianten representeert (zie figuur 1). Wanneer ik daar de consumenten 'A' en 'B' op plaats, dan kunnen $A$ en $B$ naarmate er meer verschillende producten beschikbaar $2 \mathrm{ljn}$, producten kopen die dichter bij hun woorkeur liggen. Als er werkelijk maatwerk wordt geboden kan ledere consument zelfs het product kopen dat precies op zijn of haar woorkeurslocatie ligt.

Ook voor producenten kunnen er voordelen aan marketing maatwerk verbonden zijn. Een van de grootste voordelen is dat producenten veel lagere voorraadkosten kunnen hebben, omdat er alleen nog op bestelling wordt geleverd (bijw. Tseng en Piller 2003). Alle producten die worden gemaakt zijn in principe al verkocht, waardoor de voorraden veel kleiner kurnen zijn. Bovendien kan maatwerk naar verwachting de concurrentiedruk tussen producenten verkleinen (bjjv. Pine, Peppers en 
Rogers 1995). De gedachte achter deze redenering is dat producent en klant gezamenlijke kennis opbouwen die door de klant maar deels overdraagbaar is aan andere producenten. Hierdoor wordt het voor klanten lastiger om naar andere producenten over te stappen, hetgeen vervolgens de concurrentiedruk verlaagt.

Is een maotwerk benadering superieur aon traditionele massaproductie?

De wetenschap zou de wetenschap niet zijn als het antwoord niet zou luiden: Dat hangt er van af. Maar waar hangt dat dan van af? In de eerste plaats zijn natuurlijk de kosten van productie en de beschikbaarheid van de benodigde flexibele technologie van belang. Daamaast is echter een belangrijke voorwaarde voor marketing maatwerk, dat meting en verwerking van consumentenpreferenties wordt geintegreerd in de voortbrengingsketen (Wind en Rangaswamy 2001). Conceptueel moet hiertoe de traditionele splitsing van het waardecreatie proces in enerzijds een voortbrengingsdeel en anderzijds een consumptie- of 'waardevernietigings' -deel worden doorbroken. In plaats daarvan dient de consument te worden gezien als een actieve partmer in de op maatwerk gerichte marketing-en productieprocessen.

Consumenten kunnen hun rol van partner in verschillende stadia van de voortbrengingsketen vervullen. Voor de overzichtelijkheid onderscheid ik vijf functionele stadia in de voortbrenging van een product of dienst: R\&D, Facilitering, Productie, Consumptie en Mazorg. Bij het tot stand brengen van maatwerk kan de consument in elk van deze stadia actief zijn. Bijwoorbeeld in de productontwikkeling en het design door nieuwe ideeën aan te reiken 'von Hippel 2001), in de productie door het moment en de componenten van productie te bepalen (Pine en Gilmore 2000), in de facilitering door de methode en locatie van betaling en aflevering te kiezen, en in de nazorg door suggesties ter aanpassing aan te reiken, bijv. in gebruikersgemeenschappen (Fattah 2002).

Bij het onderzoeken van de vraag of, en zo ja in welke mate, consumenten en producenten baat hebben bij deze nieuwe invulling van de keten en de introductie van een op maatwerk gericht voortbrengingsproces, is het begrip 'marketing efficiency' van Wenerfelt (1984) een bruikbaar concept. in zijn analyse poneert Wernerfelt dat op termijn alleen die marketing benaderingen in de markt overleven dle tenminste Pareto optimaal zijn ten opzichte van andere benaderingen. Dat wil zeggen dat er alleen marketing benaderingen in de markt kunnen bestaan waaraan geen enkel aspect verbeterd kan worden zonder dat andere aspecten van deze benaderingen verslechteren. Dit betekent bijvoor- 
beeld dat in de markt een flexibele, snelle en dure productie methode wel naast een reguliere en goedkope productiemethode kan overleven, maar niet nast een tweede flexibele, snelle productiemethode die wel goedkoop is.

Marketing maatwerk moet daarom tenminste meerwaarde voor consumenten en producenten gezamenlijk opleveren ten opzichte wan meer traditionele marketingsystemen wil het als bedrijfsaanpak kunnen overleven in de markt. Meer concreet houdt dit veelal in dat geen van de betrokken partijen deel zal willen nemen aan een op maatwerk gerichte marketing benadering wanneer er voor elk afzonderlijk miet tenminste een gelijke opbrengst is te behalen als bij de reeds bestaande marketing benaderingen. Zowel de keuze van producenten als van consumenten om deel te nemen aan op maatwerk gerichte voortbrengingsketens vormen daarom een interessant onderzoeksterrein met belangrijke implicaties.

\section{De consumentenkeuze voor marketing maatwerk}

In enkele recente onderzoeken hebben we de consumentenkeuze om deel te nemen aan marketing maatwerk nader onder de loep genomen. Uitgangspunt in deze analyses zijn nutsmodellen van consumenter keuzegedrag (bijv. MicFadden 1986). In deze modellen wordt de kans dat consumenten een bepaald product aanschaffen of een bepaalde dienst gebruiken uitgedrukt als een functie van de kenmerken van het product of de dienst, de kenmerken van concurrerende producten of diensten, de kenmerken van de consument en de kenmerken van mogelijk relevant omgevingsvariabelen, zoals bijvoorbeeld het weer. De kans dat consumenten voor marketing maatwerk kiezen kan ook met een dergelijk model worden uitgedrukt. Naarmate de kenmerken van marketing maatwerk aantrekkelijker worden ten opzichte van andere reeds bestaande alternatieven, neemt de kans dat voor maatwerk wordt gekozen toe.

Bij het analyseren wan de consumentenkeuze voor marketing maatwerk is het daarom belangrijk om de voor-en nadelen van maatwerk voor consumenten goed in kaart te brengen. Het blijkt dat naast het voordeel van een product dat beter aansluit bij de eigen smaak er woor consumenten ook nadelen aan marketing maatwerk zijn verbonden in de worm van mogelijke kosten en onzekerheden die horen bij het kopen van producten en diensten op mat. Een van de belangrijkste nietfiranciële nadelen voor consumenten werbonden aan marketing maat- 
werk zijn de zogenaamde complexiteitskosten. Complexiteit vormt een nadeel voor consumenten orndat het menselijk brein beperkt is in zijh cognitieve capaciteiten en meestal niet in staat is alle aspecten van een beslissing te overzien (Simon en Newell 1972). Bij de aanschaf wan producten en diersten op maat moeten consumenten echter noodgedwongen een zeer groot aantal kenmerken vergelijken en beoordelen, vaak zonder dat ze alle gevolgen van hun keuzes kunnen kennen (bijv. Huffman en Kahn 1998). Een dergelijke complexiteit wordt door consumenten als onaantrekkelijk gezien en verlaagt de kans dat ze voor een maatwerk traject zullen kiezen.

In twee recente projecten heb ik met een aantal coauteurs deze afweging in de consumentenkeuze om wel of niet voor een maatwerkaanpak te kiezen verder onderzocht. In een project heb ik met Stefan Stremersch (Erasmus Universiteit) een nutsmodel ontwikkelid om de invioed te schatten van verschillende kenmerken van de marketing maatwerk benadering (zoals bijvoorbeeld het aantal modules waar. binnen de consument een kevze kan maken), de expertise van consumenten, de complexiteit van het maatwerkproces en de verwachte aantrekkelijkheid wan het product dat kan worden samengesteld, op de kans dat consumenten een bepaald systeem van maatwerk zullen accepteren (Dellaert en Stremersch 2002). Figuur 2 illustreert de structuur van dit model.

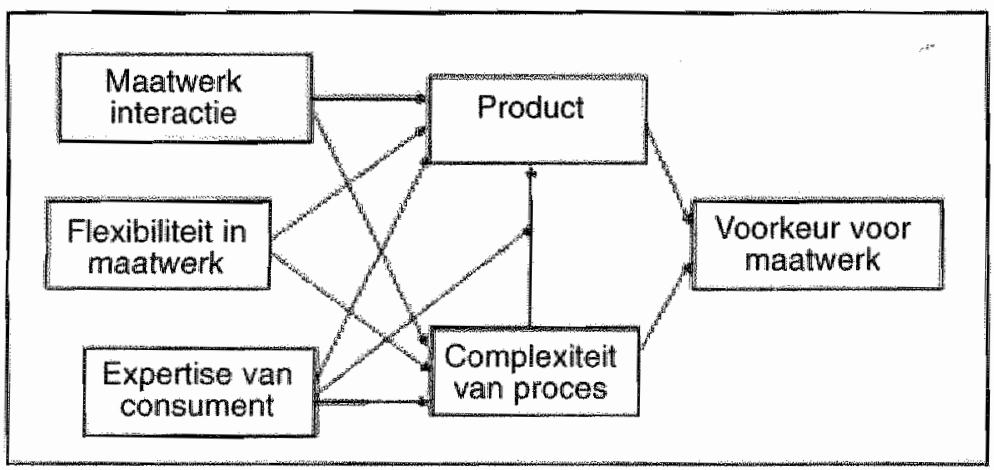

Figuur 2. Structuur van de consumentenvoorkeur voor matwerk 
Het model hebben we getoetst op consumentengegevens die zijn verzameld via het internet. We vroegen respondenten om in denkbeeldige situaties hun ideale PC samen te stellen op werschillende websites die leken op de bestaande Dell website. Op basis van recent ontwikkelde modelbenaderingen en schattingstechnieken konden we het gelijktijdig effect van al deze kenmerken op de keuzes van consumenten bepalen en bovendien nagaan in hoeverre de smaken van verschillende consumenten onderling afweken (zie bijwoorbeeld Ashok, Dillon en Yuan 2002 en Train 2003).

Uit de resultaten van dit project blijkt dat de complexiteit van het matwerk proces inderdaad het verwachte negatief effect heeft op de kans dat consumenten er aan deel zullen nemen. Boveridien blijkt complexiteit ook een negatief effect te hebben op het oordeel van de consument over het product dat zij in het maatwerkproces zelf samenstellen. Hoe complexer de taak hoe minder aantrekkelijk men het product vindt. Tenslotte vinden we dat de deskundigheid van de consument deze effecten beïnwloedt. Deskundige consumenten hebben een grotere waardering woor extra keuzemogelijkheden en zijn minder gevoelig voor complexiteit.

In een tweede project, dat ik samen met Pratibha Dabholkar (University of Tennessee) en Jens Coebel, een van onze afstudeerders, uitvoer, wordt verder in detail onderzocht welke onderliggende latente factoren bepallen of consumenten maatwerk aantrekkelijk vinden. De productcategorie die we in deze studie gebruiken is spijkerbroeken. Er is tegenwoordig een aantal kledingzaken op het Internet waar je je spijkerbroek op maat kunt laten maken, zoals bijvoorbeeld de firma Lands End (Ives en Piccoli 2003). Uit onze resultaten blijkt dat in lijn met recente uitbreidingen wan het zogeheten Technology Acceptance Model (Davis, Bagozzi en Warshaw 1989) naast het gebruiksgemak of complexiteit, ook het plezier in het gebruik van het maatwerk proces een belangrijke rol speelt. Bovendieli maken consumenten zich zorgen over de mate waarin zij het proces kunnen beheersen (Dabholkar 1996) en blijkt dat in de context van marketing maatwerk het concept "bruikbaarheld" doeltreffend kan worden gemeten in termen van de verwachte aantrekkelijkheid van het product dat de consument kan samenstellen.

In een derde project samen met Hans van Trijp, Oxana Riaboukhina, Frans Verhees (Wageningen UR) en Sonja Wendel "een van onze promovendi, gaan we nog een stap verder en bezlen niet alleen in hoeverre consumenten bereid zijn om een complex interactieproces aan te gaan 
met een producent, maar ook of ze daarbij privacy gevoelige informatie over hun gezondheld willen delen om in ruil daarvoor een persoorilijk voedingsiadvies te kunnen verkrijgen. Daarnaast wordt de rol van de gebruikssituatie waarin de consument zich bevindt (bijv. zijn of haar omgeving) in dit project bestudeerd omdat eerdere onderzoeken thebben aangetoond dat consumentenpreferenties sterk situationeel gebonden kunnen zijn (bijv. Beik 1975. Seybold 2001). We verwachten daarom dat veranderingen in situatie een belangrijke invloed kunnen hebben op de vraag of consumenten wel of niet voor marketing maatwerk zullen kiezen. De dataverzameling voor dit project wind momenteel plaats.

\section{De productkeuze in een marketing maatwerk context}

Naast de keuze om all dan niet deel te nemen in marketing maatwerk, is ook een tweede type consumentenkeuze van belang, namelijk de keuze van een specifiek product of een specifieke dienst binnen de maatwerk context. Eerder onderzoek heeft aangetoond dat de productkeuze van consumenten kan afhangen van de wijze waarop de wergelijking tussen producten wordt gepresenteerd (bijv. Kahmeman en Tversky 1984, Payne 1982). Het is dan ook aannemelijk dat verschillen in de processen am consumentenvoorkeuren in kaart te brengen en de wijze waarop bijvoorbeeld maatwerk modules worden vergeleken ook zullen leiden tot verschillen in productkeuzes.

Recent onderzoek bevestigt deze verwachting (Huber, Ariely en Fischer 2001). Een terrein waarop met name veel onderzoek is gedaan is de rol van persoonlijke aanbevelingen voor producten die zo goed mogelijk bij de voorkeuren van de consument moeten aansluiten (bijv. Diehl, Kornish en Lynch 2003). Bijvoorbeeld websites als Activebuyersguide.com maken dit type van diensten mogelijk. In de eerste plaats blijkt uit dit onderzoek dat aanbevelingen consumenten enorm kunnen helpen bij het kiezen van die producten die zo dicht mogelijk tegen hun woorkeuren aanliggen. Bovendien kost het ze minder moeite om dergellike producten te selecteren (Häubl en Trifts 2000). Daarnaast blijkt er een aantal verschuivingen in de voorkeuren plaats te vinden. Zo blijkt uit een recent onderzoek dat ik met Gerald Häubl (University of Alberta), heb verricht dat consumenten in een lijst met aanbevelingen andere heuristieken gebruiken dan wanneer zij op basis van toeval gerangschikte producten onder ogen kriggen. Ook is bekend uit andere onderzoeken dat de voorkeuren van consumenten sigmificant beinvloed worden door de kenmerken waarover zij naar hun voorkeur 
Zlin gevaagd (Häubl en Murray 2003, Häubl, Dellaert, Murray en Trifts 2003).

\section{De verdeling van meerwaarde tussen producent en consument}

Wanneer er door de benutting van marketing maatwerk daadwerkelijk meerwaarde in de keten tot stand wordt gebracht, dan doet zich vervolgens de vraag woor hoe die gerealiseerde meerwarde wordt ver. deeld. Zal de meerwaarde bijvoorbeeld tot gevolg hebben dat de con. sument voor hetzelfde geld en dezelfde moeite een aantrekkelijker pro. duct krijgt, of wordt de meerwaarde eerder vertaald in een hogere winstmarge voor de producent die maatwerkproducten tegen een hogere prijs kan verkopen?

Bij de analyse van deze vraag speelt een aantal strategische vraagstukken. Een eerste belangrijke vraag is op welke basis de verdeling wan meeropbrengsten tot stand komt. Hiermee hangen ook de vragen samen hoeveel meerwaarde elke speler in de voortbrengingsketen toevoegt en welke speler de meest dominante partij in de keten vormt (bijw. Brandenburger en Nalebuff 1996). In een studie met Stefan Stremersch, Allen Weiss (University of Southern California) en Ruud Frambach (Vrije Universiteit) hebben we bijwoorbeeld onderzoek gedaan naar de factoren die bepalen of bedrijuen zelf de regie willen houden bij het integreren van verschillende moduies in een complex technische systeem of dat zij de integratie activiteit juist uit willen besteden aan een derde partij (5tremersch, Weiss, Dellaert en Frambach 2003). Onze bevindingen laten zien dat in de sterk technologische markt voor telecommunicatiesystemen, de kennis van het bedrijf en zijn toeleveranciers een zeer belangrijke rol speelt bij deze beslissing. Bedrijven die zelf veel kennis hebben, besteden de integratie activiteit liever niet uit. Dit effect kan echter worden gecompenseerd door een grote deskundigheid van toeleveranciers of een grote technologische onzekerheid in de markt, orridat daardoor de waarde van kennis snel kan vervluchtigen.

In de tweede plats is er de verdeling tussen de consument en de voortbrengingsketen. Een veel gehoord argument voor marketing maat* werk is dat het de concurrentie tussen voortbrengingsketens vermin* dert (Pine, Peppers en Rogers 1995). De belangrijkste reden hiervaor is dat er leereffecten plaatsvinden, waarbij consumenten en producenten gaandeweg expliciete en impliciete kennis verwerven die moeilijk overdraagbaar is en die transacties tussen consument en ketenpartners vergemakkelijken en verbeteren. In dit geval wordt met name de positie 
van de producent ten opzichte van de consument versterkt, omdat de overstapkosten voor de consument toenemen naarmate er meer maatwerk wordt geboden. Denk bifvoorbeeld aan de moeite die het (nu al) kost om van verzekering of bank te veranderen en hoe die nog zou worden vergroot als u bij elke organisatie opnieuw een individuele op maat gemaakte website zou moeten samenstellen, uw persoonlijke contactpersoon zou moeten bijpraten en uw persoonlijke polis- of hypotheekvoorwaardien zou moeten vaststellen.

In een onderzoek met Niladri Syam en Ranran Ruan (University of Houston! nemen we deze strategische interactie tussen consumenten en producenten in marketing maatwerk nader onder de loep in een speltheoretische analyse (Syam, Ruan en Dellaert 2003). De studie laat zien dat het leveren van maatwerk inderdaad de concurrentiedruk kan verminderen, malar alleen onder bepaalde woorwaarden. Conceptueel is namelijk een van de meest interessante resultaten van deze studie dat: als elk bedrijf in een markt maatwerk aan zou bieden voor elk ken merk van de producten, dit de concurrentie sterk vergróót in plaats van verkleint. De reden is dat in dat geval elk product rechtstreeks concurreert met elk ander product. Er is geen enkel competitief voordeel meer, omdat alle producenten alle consumenten precies op maat kumnen bedienen. Daarom is een conclusie in dit onderzoek dat bedrijven maatwerk slechts voor een deel van alle productkenmerken zullen aanbieden. Bovendien zullen zij dit zoveel mogelijk voor dezelfde kenmerken doen, om zo ruimte voor concurrentievoordeel op de andere kenmerken te kunnen bewerkstelligen.

De studie laat werder zien dat ondanks dit concurrentievoordeel de prijs van maatwerk producten voor consumenten veelal gelijk zal zijn aan reeds bestaande producten in de markt. De reden hiervoor is dat de producent bij het leveren van maatwerk afhankelijk is van de input van de consument. Wanneer de prijs van maatwerkproducten te hoog wordt zal de consument niet bereid zijn om de benodigde productspecificaties door te geven aan de producent en in plaats daarvan kiezen voor een goed standaard alternatief in de markt.

\section{Niet alles hoeft, lkan, moet maatwerk zijn}

Na dit overzicht van verschillende aspecten van marketing maatwerk en hoe consumenten en producenten daarmee omgaan, will ik nog aandacht besteden alan enkele factoren die de rol van maatwerk begrenzen. De rol van deze factoren vormt deels een open veld voor werder onder- 
zoek en deels een min of meer logische beperking van de rol van maatwerk, waarvan het relatief belang in de markt nog moet worden vastgesteld.

\section{Smaken verschillen, maar niet altijd}

Het succes van maatwerk staat of valt grotendeels met de aanwezigheid van heterogeniteit in de vraag. Als ieder individu écht het liefst in een blauwe overall zou lopen, dan valt er woor hightech flexibele productiesystemen weinig eer te behalen. Gelukkig is het zo dat op de meeste terreinen smaken verschillen en dat consumenten bijwoorbeeld hun eigen identiteit in hun kleding tot uitdrukking willen brengen.

Maar er zijn grenzen aan de behoefte om uniek te zijn. Nadat ik Melissa's make over had bewonderd op het Internet, wierp ik ook een blik op enkele andere kandidaten: Sandra, Karen en Tammy. Wat mij naast de spectaculaire wijzigingen aan hun uiterlijk nog het meest op viel, was hoezeer zij na hun make-over op elkaar leken. Kennelijk kwamen hun persoonlijke woorkeuren sterk overeen en betekende matwerk woor hen de vervulling van een vergelijkbare uiterlijke schoonheidswens. Het is waarschijnlijk dat ook voor sommige andere producten en diensten de consumentenwoorkeuren niet zo ver uiteen zullen lopen, bijwoorbeeld omdat zij grotendeels biologisch of sociaal-cultureel bepaald zijn.

Ook wanneer er sterke (sociale) netwerk-externaliteiten optreden bij consumptie kan differentiatie in maatwerk onaantrekkelijk zijn woor consumenten. Op het gebied van kleding bestaat er voor de consument bijvoorbeeld het risico dat de kleding die hij of zij zelf samen stelt niet in de mode is waardoor het (deels) beoogde effect om anderen te imponeren teniet wordt gedaan. Coördinatie van de smaak kan in een dergelijke situatie een belangrijke taak van de producent zijn.

\section{Gedeelde consumptie}

Een hieraan gerelateerde beperking aan marketing maatwerk is dat een groot aantal producten en diensten wordt geconsumeerd door meerdere consumenten tegelijk. Bijvoorbeeld in het gezin zijn smaken vaak verschillend en is het niet mogelijk of wenselijk dat een product op maat wordt gemaakt naar de smaak van slechts één gezinslid (Aribarg. Arora en Bodur 2002). Bovendien blijkt dat gezinsleden vaak slecht van elkaars preferenties op de hoogte zijn, hetgeen de groepsbeslissing over een product of dienst op maat (bijvoorbeeld een vakantie) aanzienlijk kan compliceren (Dellaert, Prodigalidad en Louviere 1998). 
Dergelijke conflicten doen zich ook op een groter schalal voor bij projecten zoals de inrichting van de openbare ruimte waar conflicten tussen de belangen van verschillende gebruikers haast onvermijdelijk zijn (Lindberg, Andersson en Dellaert 2001). In een onderzoek in samenwerking met Qi Han, Harry Timmermans (T.U. Eindhoven) en Fred van Raaij (Universiteit van Tilburg) bezien we in hoeverre dergelijke conflicten deels kunnen worden beperkt door elke gebruiker (in dit geval toeristen in de stad) individuele adviezen te geven over waar en wanneer verschillendle activiteiten het best kunnen worden ondernomen $(\mathrm{Oi}$, Dellaert, Timmermans en van Raaij 2003). In deze adviezen wordt rekening gehouden met de activiteiten van andere gebruikers waardoor de totale gebruikscapaciteit en de beleving van de ruimte kan worden verbeterd.

\section{Wees of word geinspireerd}

Behalve de coördinatie tussen gebruikers onderling, kan ook de rolverdeling tussen producent en consument een reden zijn om maatwerk te beperken. Bijvoorbeeld op het vlak van productinnovatie is het soms de vraag of de consument de meest geschikte partij is om deze tot stand te brengen. De deskundigheid van de producent op het terrein van een bepaald product is vaak groter dan die van de consument en dit is een van de redenen waarom producenten veelal de rol van innovator op zich nemen. Een alternatieve benadering is om alleen deskundige consumenten te betrekken bij innovaties en op die manier horizontale in plaats van verticale specialisatie in de keten tot stand te brengen (von Hippel 2002).

In beide gevallen geldt echter dat het merendeel van de consumenten waarschijnlijk niet in staat is, of de behoefte heeft, om zelf innovaties tot stand te brengen. Misschien dat een schilderij van Rembrandt op maat nog voor te stellen is, of wie weet zelfs wel gerealiseerd, voor een Mondriaan is dat al moeilijker. In beide gevallen bepaalt bovendien de kunstenaar vóóraf de stijldefinities en niet de koper zelf, Op een meer abstract niveau zou ik durven stellen dat het haast een voorwaarde is voor inspiratiebronnen dat deze niet door het individu zelf kunnen wor. den gegenereerd. Ook een wandeling in de natuur kan moeilijk inspirerend zijn als de wandelaar gaandeweg zelf deze natuur moet definiëren.

Toch ontrolt zich ook op dit vlak een interessant spanningsveld. Hoewel de consument geinspireerd en uitgedaagd wil worden, wil hil of zij tegelijkertijd zoveel mogelijk greep houden op deze uitdagingen. De hedendaagse consument begeeft zich daarom in zeer gecontroleerde 
'speel' ormgevingen waarbinnen de uitdaging of inspiratie vaak zeer eng gedefinieerd is en eendimensionaal van karakter (bijw Eco 1986). De vele extreme sporten, themaparken en verre reizen die tegenwoordig worden geconsumeerd wormen in zekere zin daarom ook modulaire ervaringen die door de consumenten naar believen kunnen worden geschakeld en die passen binnen zeer strak en geavanceerd systeem wan informatiesystemen, logistieke systemen en institutionele kaders.

\section{Categorisatie en communicatie}

Een ander aspect wan de voortbrengingsketen waar een zekere centralisatie en afsternming in de keten van belang is, is cle communicatie over de producten of diensten die worden voortgebracht. Een van de belangrijkste middelen om een krachtig merk op te bouwen is consistentie in de uitingen over dit merk (Erdem en Swait 1998). Een dergelijke consistentie vergroot de herkenbaarheid en geloofwaardigheid van het merk. Nike stelt de consument in staat om zelf zijn of haar nieuwe schoenen vormi te geven, maar het merk moet daarbij wel een gemeenschappelijk imago van "coolness" en kwaliteit zien te handhaven voor al zijn producten. De merknaam en sommige stijlelementen kunnen daarom niet als maatwerk worden aan geboden. Als Nike het toe zou staan dat Mike en Spike ook hun eigen 'swosh' zouden ontwerpen en op hun gymschoenen zetten, dan zou het waarschijnlijk snel met het merk gedaan zijn.

Hieraan gerelateerd is de vraag hoe met consumenten het best kan worden gecommuniceerd over de mogelijkheden van een bepaalde voortbrengingsketen. Naarmate de flexibiliteit van de keten groter

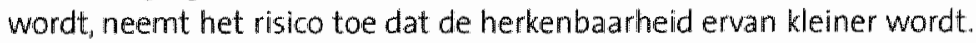
Een advertentie ter promotie van alles wat in naaiateliers kan worden gemaakt' is waarschijnlijk weinig aansprekend voor de meeste consumenten. Zakenpakken op maat daarentegen vormen wel een heldere propositie die nu met succes wordt uitgebaat door possen.com, een bedrijf dat is gesticht door een van de afgestudeerden van onze faculteit. Het is dus zaak om de juiste categorieen te vinden om maatwerk in onder te brengen, want een fiets met vier wielen, twee stoelen, een toeter, een dak ${ }_{r}$ ramen en een motor, zal door de meeste consumenten niet als zodanig therkend worden, ook al was Koning Krentebol die hem bestelde er zeer tevreden mee! (Busser en Schröder 2001). 


\section{Dankwoord}

Aan het eind van deze rede wil ik graag een aantal personen en instellingen bedanken voor hun ondersteuning bij mijn activiteiten in de loop der jaren. Allereerst wil mijn huidige collega's en studenten bij het departement Marketing van de Faculteit de Economische Wetenschappen en Bedrijfkunde bedanken. Dankzij jullie enthousiasme en openheid voelde ik me hier in korte tijd zeer thuis en zijn inmiddels al een groot aantal veelbelovende projecten opgestart waarvan enkele al artikelen hebben opgeleverd die binnenkort kunnen worden gepubliceerd. Ook wil ik het bestuur van de faculteit en de facultaire onderzoeksschool METEOR bedanken voor het in mij gestelde vertrouwen en voor de bijzondere kans om mij in het kader wan de METEOR leerstoel in de komende jaren sterk op onderzoek te richten.

Daarnaast wil ik mijn collega's bedanken aan eerdere universiteiten waar ik heb gewerkt, onder andere bij de marketing vakgroepen aan de Universiteit van Tilburg en de University of Sydney en de sectie urba. nistiek aan de Technische Universiteit Eindhoven. Zonder de vele inspirerende en stimulerende discussies die we hebben gevoerd was mijn onderzoek en onderwijs van nu nooit geworden wat het is. Een speciaal woord van dank voor mijn promotoren Harry Timmermans en Jordan Louviere, die mij het wetenschappelijk bedrijf hebben leren kennen en die mij ook in mijn verdere loopbaan vele waardewolle inzichten hebben gegeven. Toen ik hen zo'n tien jaar geleden leerde kennen wist ik maar weinig af van keuzemodellen of marketing, inmiddels zijn het mijn specialismen. Tevens wil ik bij deze gelegenheid graag Joost van Andel en Toon van de Ven kort herdenken. Zij gaven mede vorm aan mijn wetenschappelijke ontwikkeling.

In loop der jaren zijn verschillende van mijn projecten, vaak in samenwerking met anderen, ondersteund door subsidiegevers. Graag wil ik ook hen bedanken voor de ondersteuning. De fondsen en adviezen van NWO-MACW, het Samenwerkingsorgaan Brabantse Universiteiten SOBU, KLICT: Ketennetwerken, Clusters en ICT, CentERdata en de faculteiten en onderzoeksscholen waar ik heb gewerkt in Maastricht, Tilburg en Sydney hebben waardevolle bijdragen geleverd bij de aanstellingen van verschillende AlO's en aan de verzameling van gegevens voor mijn onderzoek.

Tevens wil ik de coauteurs en promovendi waar ik in de loop van de jaren mee heb samengewerkt van harte bedanken voor de wruchtbare uitwisselingen van ideeèn en ervaringen. Op het gebied van het marke- 
ting maatwerk onderzoek dat ik vandaag heb besproken wil ik met name Gerald Häubl, Stefan Stremersch en Niladri Syam bedanken woor de zeer prettige en leerzame samenwerking.

Tot slot een laatste dankwoord aan mijn familie en vrienden. Allen hartelijk bedarnt woor jullie belangstelling en steun door de jaren heen. Guus en Bernie dank je wel voor alle hulp en enthousiasme vanaf het eerste begin tot aan nu. Astrid, Jasper en Stan, jullie liefde en het plezier dat we samen hebben, betekenen heel veel voor mij en straks doen we snel een echte "family hug'!

Allen hartelijk dank voor uw belangstelling.

Ik heb gezegd. 


\section{Literatuur}

Aclirol, Ravi S. en Philip Kotler (1999). "Marketing in the Network Economy." Journal of Marketing 63(Special Issue), 146-163. Anderson, David M. (1997), Agile Product Development for Mass Customization, Chicago: Irwin.

Aribarg, Anocha, Neeraj Arora en H. Onur Bodur (2002) "Understanding the Role of Preference Revision and Concession in Group Decisions". Journal of Marketing Research 39 (August). 336-349 Ashok, Kalidas, William R. Dillon en Sophi Yuan (2002), "Extending

Discrete Choice Models to Incorporate Attitudinal and Other Latent Variables," Journal of Marketing Research 39 (February), 31-46. Blair, John G. (1988), Modular America: Cross-Cultural Perspectives on the Emergence of an American Way, New York: Greenwood Press. Beck, Ulrich en Elisabeth Beck-Germsheim (2002), Individualization, London: Sage Publications.

Belk, Russel W. (1975), "Situational Variables and Consumer Behavior," Joumal of Consumer Research, 2(December), 157-164.

Brandenbruger, Adam M. en Barry J. Nalebuff (1996), Co-opetition, New York: Dowbleday.

Busser, Marianne en Ron Schröder (2001), Het Grote Verhaaltjesboek, met tekeningen van Wilbert van der Steen, Houten: Van Holkema \& Warendorf.

Dabholkar, Pratibha (1996), "Consumer Evaluations of New TechnologyBased Self-Service Options: An Investigation of Alternative Models of Service Quality," International Nournal of Research in Marketing 13(1), 29-51.

Davis, Fred D., Richard P. Bagozzi en Paul R. Warshaw (1989), "User Acceptance of Computer Technology: A Comparison of Two Theoretical Madels," Management Science 35(8), 982-1004. Dellaert, Benedict G.C., Mia Prodigalidad en Jordan J. Louviere (1998), "Family Members' Projections of Each Other's Preference and Influence: A Twa-Stage Conjoint Approach." Marketing Letters 9(2), $135-146$.

Dellaert, Benedict G.C. en Stefan Stremersch (2002), "When Do Consumers Mass Customize? An Extended Choice Modeling Framework," onder review bij Journal of Marketing Research. Diehl, Kristin, Laura Kornish en John G. Lynch (2003). "Smart Agents: When Lower Search Costs for Quality Information Increase Price Sensitivity," Journal of Consumer Research 30(June), 56-71. 
Eco, Umberto (1986), Travels in Hyperreality, London: Pilcador. Erdem, Tulin en Joffre Swait (1998), "Brand Equity as a Signaling Phenomenon," Joumal of Consumer Psychology 7(2), 131-157. Fattah, Hassan M. (2002), P2P: How Peer-to-Peer Technology is Revolutionizing the Way We Do Business, Chicago: Dearborn. Han, Oi, Benedict G.C. Dellaert, W. Fred van Raaij en Harry J.P.

Timmermans (2003), "Tourist Activity Planning in Congested Urban Tourism Environments: Towards a Game-Theoretic Model and Decision Support System," in Geoffrey.1. Crouch, Rick R. Perdue, Harry J.P. Timmermans en Muzzafer Uysal eds. Consumer Psychology of Tourism, Hospitality and Leisure 3rd edition, te verschijnem. Häubl, Gerald, Benedict G.C. Dellaert, Kyle B. Murray, en Valerie Trifts (2003). "Buyer Behavior in Personalized Shopping Environments: Insights from the Institute for Online Consumer Studies," in CM. Karat, J. Blom, en J. Karat eds., Designing Personalized User Experiences for eCommerce, Ansterdam: Klluwer te verschijnen.

Haubl, Gerald en Kyle Murray (2003), "Preference Construction and Persistance in Digital Market Places: The Role of Electronic Recommendation Agents, "Journal of Consumer Psycholagy 13(1), $149-159$.

Häubl, Gerald en Valerie Trifts (2000), "Consumer Decision Making in Online Shopping Environments: The Effects of Interactive Decision Aids," Marketing Science $19(1), 4-21$.

Huber, Joel, Dan Ariely and Gregory Fischer (2001), "Expressing

Preferences in a Principal-Agent Task: A Comparison of Choice, Rating and Matching," working paper, Department of Marketing, Fuqua School of Business, Duke University. Huffman, Cynthia en Barbara E. Kahn (1998), "Variety for Sale: Mass Customization or Mass Confusion," Journal of Retailing 74i4) "491-514. ives, Blake en Gabriele Piccoli (2003) "Custom Made apparel and Individualized Service at Land's End, "Communications of the Association for information Systems 11, 79-93.

Kahneman, Daniel and Amos Tversky (1984). "Choices, Values and Frames," American Psychologist 39. 341-350. Lindberg, $\mathrm{Kreg}$, Tommy D. Andersson en Benedict G.C. Dellaert (2001), "Tourism Development: Assessing Social Gains and Losses," Annols of Tourism Research 28(4), 1010-1030.

McFadden, Daniel (1986), "The Choice Theory Approach to Market

Research," Marketing Science 5(4), 275-298. 
Newell, Allen en Herbert A. Simon (1972), Human Problem Solwing, Englewood Cliffs, N.J.: Prentice-Hall.

Payne, John (1982), "Contingent Decision Makeing: A Review and Discussion of issues," Psychological Bulletim 73, 221-230.

Prahalad, C. K. en Venkatram Ramaswamy (2000), "Co-opting Customer Competence," Harvard Business Review 78(1), 79-87.

Pine, Joseph B. en James H. Gilmore (2000), Markets of One: Creating Customer-Unique Value through Mass Customization. Boston: HBS Press.

Pine, B. Joseph II, Don Peppers en Martha Rogers (1995), "Do You Want to Keep Your Customers Forever?" Harvard Business Review 73(2), $103 * 114$.

Rifkin, Jeremy (2000), The Age of Access: How the Shift from Ownership to Access is Transforming Modern Lffe, London: Penguim books.

Sanchez, Ron (1999), "Modular Architecture in the Marketing Process," Joumal of Marketing 63(Special Issue), 92-11.

Seybold, Patricia B. (2001), "Get Inside the Lives of your Customers," Harvard Business Rewiew, 79 (5), 80*9o.

Stremersch, Stefan, Allen M Weiss, Benedict G.C. Dellaert en Ruud T. Frambach (2003). "Buying Modular Systems in Technology-Intensive Markets," Journal of Marketing Research 4o(August), 335-350.

Syam, Niladri B., Ranran Ruan en Benedict G.C. Dellaert (2003) "Consumer-Producer Interaction: A Strategic Analysis of the Market for Customized Products," onder tweede review bij Marketing Science Train, Kenneth E. (2003), Discrete Choice Methods with Simulation, Cambridge, UK: Cambridge University Press.

Tseng, Mitchell M. en Frank T. Piller (2003), "The Customer Centric Enterprise: Advances in Mass Customization and Personalization," Berlin: Springer Publishers.

Ritzer, George (1998), The McDonaldization Thesis, London: Sage Publications.

Von Hippel, Eric (2001), "Perspective: User Toolkits for Innovation," Journal of Product innovation Management 18(4), 247 257

Von Hippel, Eric (2002), "Horizontal Innovation Networks: By and For Users," MIT Sloan School of Management Working Paper 4366-o2 (June). Wernerfelt, Birgir (1994). "Án Efficlency Criterion for Marketing Design," Journal of Marketing Research 31(4), 462-477.

Wind, Jerry en Arvind Rangaswamy (2001), "Customerization: The Next Revolution in Mass Customization," Journal of Interactive Marketing 15(1): $13-32$ 